\title{
THE PROBLEM OF THE IDENTIFICATION OF THE RIACE BRONZES: A LITERARY APPROACH
}

It seems to me that it is necessary to highlight how the recent analyses on the casting materials of the two Riace statues have demonstrated that the two Bronzes were made in Argos, in the Peloponnese, in the same period and in the same workshop. Why are those hypotheses which do not take this last data into account still taken into consideration, if not even promoted by the media? Why do we consider archaeology according to a scientific pattern which is different from that of medicine and physics?

What scientist of any other branch or discipline would dare to suggest theories in marked contrast to the evidence of laboratory data? This is possible in archaeology, but it is its greatest limitation, which is condemning it to irrelevance. But perhaps another way is possible...

In my opinion, for a successful interpretation of the Riace Bronzes another element of clarification had to be inserted: the "Lille Papyrus". With an extraordinary stroke of luck, at least as far as we are concerned, Stesichorus' fragment offers us the text of the speech that the mother of Eteocles and Polynices, in the group of the Bronzes that we identify with the world-famous "Fratricides" by Pythagoras of Rhegion, addresses to her sons who are about to confront each other in a mortal duel. Bronze statues that look like actors on a stage! A conception of art that seems highly modern, but still dates back to the Severe Style, the first period in which Hellenes gave the world an art able to be a perfect mimesis, imitation of reality.

Keywords: Greek Archaeology; Iconography; Greek Art; Bronzes of Riace; Greek statues.

Даниеле Кастрицио

(Ун-т Мессины, Италия)

\section{Проблема интерпретации бронзовых статуй из Риаче: литературный подход}

Анализ состава бронзы показал, что обе статуи из Риаче были созданы в Аргосе, в одной мастерской и в одно время, но для интерпретации важны в первую очередь данные археологии, которые не берутся в расчет.

По мнению автора, для успешной интерпретации бронзовых статуй из Риаче следует использовать Лилльский папирус с поэмой Стесихора, от которой сохранилась речь матери Этеокла и Полиника, пытавшейся прекратить вражду сыновей. В статуях из Риаче предла- 
гается видеть широко известную в античности «группу братоубийц», созданную Пифагором из Регия в рамках концепции искусства, выглядящей очень современно, но которая отражает стиль, датируемый временем Северов. В это время греки подарили миру искусство, способное подражать действительности.

Ключевые слова: Греческая археология, греческое изобразительное искусство, статуи, бронзовые статуи из Риаче.

\section{Status quaestionis}

The history of the studies on the Riace Bronzes mainly consists of interventions by archaeologists and historians of Greek art who have often used the traditional "philological method", born in the nineteenth century, and based on comparisons between original statues and copies, which were created in different eras and made with different materials. The philological method is a system that has no objective elements to enhance the works, which are compared, as a matter of fact it is mainly based on the sensitivity, inspiration, and ability of visual analysis of the researcher.

As far as I am concerned, the result is often completely arbitrary and without any scientific value.

If one reads the results of the majority of the research on the statues from Riace, until the last authoritative interventions, it is possible to notice that the greatest experts, who expressed their opinions with dogmatic certainty, are in open contrast with each other. For example, some of these experts affirmed that the Bronzes are dated to the $5^{\text {th }}$ century B.C. and others claimed that they are dated to the $1^{\text {st }}$ century of our era. Then, someone believes that these statues were realized in two different moments, such as twenty or more years apart, while others presumes that they are contemporary.

The two statues should depict warriors ${ }^{1}$, deity (Roma 2007) or athletes (Di Vita 1984; Stucchi 1986; 1988), rulers (Brinkmann $2015)$ or eponymous heroes ${ }^{2}$, characters of the Trojan War myth (Sismondo Ridgway 1984) or generic strategists (Rebaudo 2020). The integration of the attributes lost over the centuries is very imaginative, starting from the possible presence of a helmet, which is located on the heads of the statues, and the possible typologies of this helmet. A researcher has recently imagined to place a Thracian hat on the head of Bronze B, called the alopekis, even though, the deformation of the skull of the statue makes the superimposition

\footnotetext{
${ }^{1}$ Arias 1984; Ross Hollaway 1975; 1988; 1991; Moreno 1998.

2 Dontàs 1984; 1985-1988; Paribeni 1984; 1986; Rolley 1983; 1984.
} 
physically impossible, with the back of the head coming out from the hat.

What about the object that the two Bronzes carried in their right hand? The hypotheses range from olive, palm branches, swords (Di Vita 1984), javelins (Moreno 1998) to spears (Stucchi 1986; 1988). Even the presence of the Hoplite Shield in the left arm has been disputed by some experts, with a theory that assumes the presence of a pelta shield on the Bronze B (Brinkmann 2015), although there are no arguments showing that this type of weapon was equipped with a porpax, an element in bronze, which is not very functional as a defence instrument made of wood or wicker, in addition it is managed with the hand and not with the arm.

Looking at the hypotheses on the place of production of the two statues, the framework becomes even more discouraging, because three different series of analysis of the clay cores have shown that the Bronzes were made in Argos, in the Peloponnese ${ }^{3}$, while scholars continue to propose Athens o Greece in general ${ }^{4}$, Delphi (Rebaudo 2020), Epizephyrian Locris (Paribeni 1984; 1986; Stucchi 1986 ; 1988) or other sites, basing themselves on arguments which do not take into account the acquired scientific data.

The data of a deep restoration suffered by the statues, with the replacement of the helmet and its fixing pin, the shield of the statue $\mathrm{A}$ and the entire right arm and left forearm of the statue B, is almost absent from the scientific bibliography. Recent studies have shown that, for replacing the damaged limbs, it was made a cast with a subsequent fusion and a final welding to the body of the statue ${ }^{5}$. The intersection of data collected by the University of Salento and the team of Koichi Hada allowed to explain a glossy black coating which is present in some areas of the two statues, assuming that it could be a painting with a sulphur-based varnish, in order to mask colour differences on the limbs after the restoration ${ }^{6}$.

As far as we are concerned, it is possible to notice that a similar resetting technique is mainly found in Rome, in the imperial era, as a matter of fact two bronze works of classical art were restored with the same system: the horse of Hegias and the Bull of the Capitoline Museums?.

\footnotetext{
${ }^{3}$ Micheli, Vidale 1996; 2003; Jones, Brunelli, Cannavò, Levi, Vidale 2016.

${ }^{4}$ Di Vita 1984; Dontàs 1984; 1985-1988; Rolley 1983; 1984.

${ }^{5}$ Buccolieri, Buccolieri, Donati, Marabelli, Castellano 2015; Castrizio 2020.

${ }^{6}$ Castrizio, Iaria 2016.

${ }^{7}$ Parisi Presicce-Touchette 2002; Castrizio 2018.
} 


\section{The bronze group of the Fratricides of Pythagoras from Reggio}

In the light of a scientific approach, the two statues of Riace proved to be almost coeval, the result of the creation of a single artist, who created the Bronze A; even though later was flanked by a younger student, who is responsible for some innovations found on Bronze B. The awareness that it is a unique statuary group, made in the Peloponnese in the middle of the fifth century B.C., made superfluous a research in the repertoire of images of Athens and Attica in the classical period, because they would certainly not have considered works from another cultural field.

The data of a restoration of the statues in Rome, however, opened up another line of research, which has given its results in the field of archaeological comparisons, as it was relatively easy to find comparisons relating to two warriors who face each other, one of them is visibly threatening, valuing the particular grimace on the face of Bronze A, which shows the teeth, made of silver.

In addition to a marble copy of the Bronze B coming from the Palatine, it must be counted a series of artifacts, all coming from the area of Rome and representing the duel of Eteocles and Polynices, the sons of Oedipus, with their mother trying in vain to divide and reconcile them: these artifacts consist of some sarcophagi, cinerary urns and even a mould for the bread used in ritual ceremonies (Castrizio 2000).

The research has shown that all finds refer to a statuary group which was well-known in ancient times. To fully understand this passage, firstly we must analyse the ways of representing the fratricidal battle in ancient times, which can be traced essentially to two main schemes: in what we like to define "Etruscan" scheme, the two brothers are in the act of wounding each other to death, in a pattern that usually sees them using the sword and with the usual presence of two demons, each behind a hero ${ }^{8}$ (Fig. 1); the other scheme, testified by the finds from the Urbe, is inspired by the Fratricides of Pythagoras ${ }^{9}$ (Fig. 2). In this second model is represented the moment before the battle, with five characters (in actual fact, they are not always represented at the same time in the archaeological remains, but with different schemes which may include three or four of them).

\footnotetext{
${ }^{8}$ Etruscan cinerary urn. Terracotta. $2^{\text {nd }}$ century BCE. Verona, MuseumLapidarium of Maffei (Museo lapidario maffeiano).

${ }^{9}$ Castrizio 2004; 2019; 2020; Castrizio, Iaria 2016.
} 


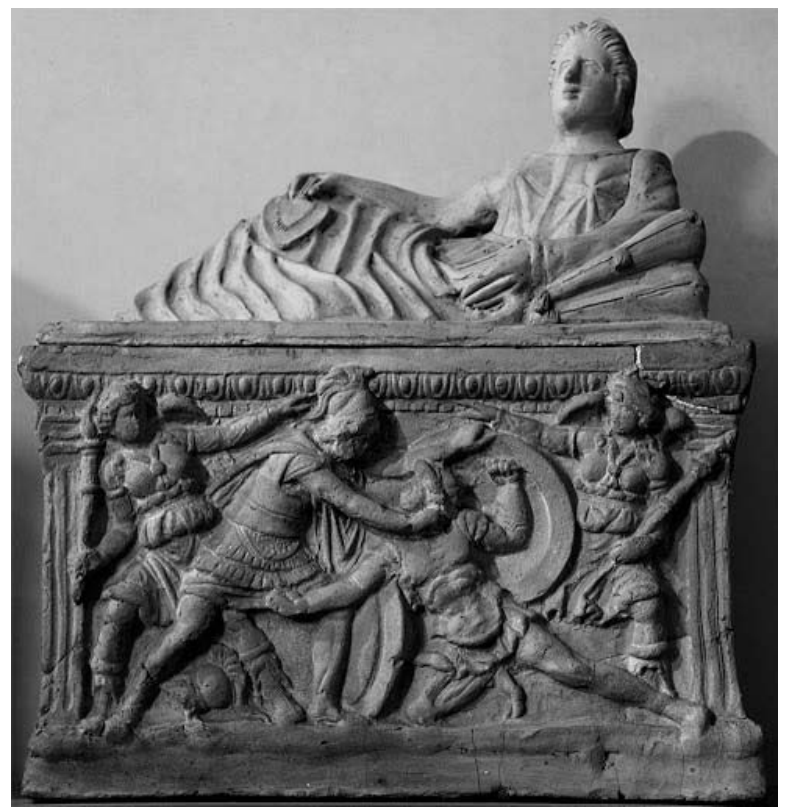

Fig. 1. Etruscan cinerary urn of Thana Heluśnei - Musei Vaticani.
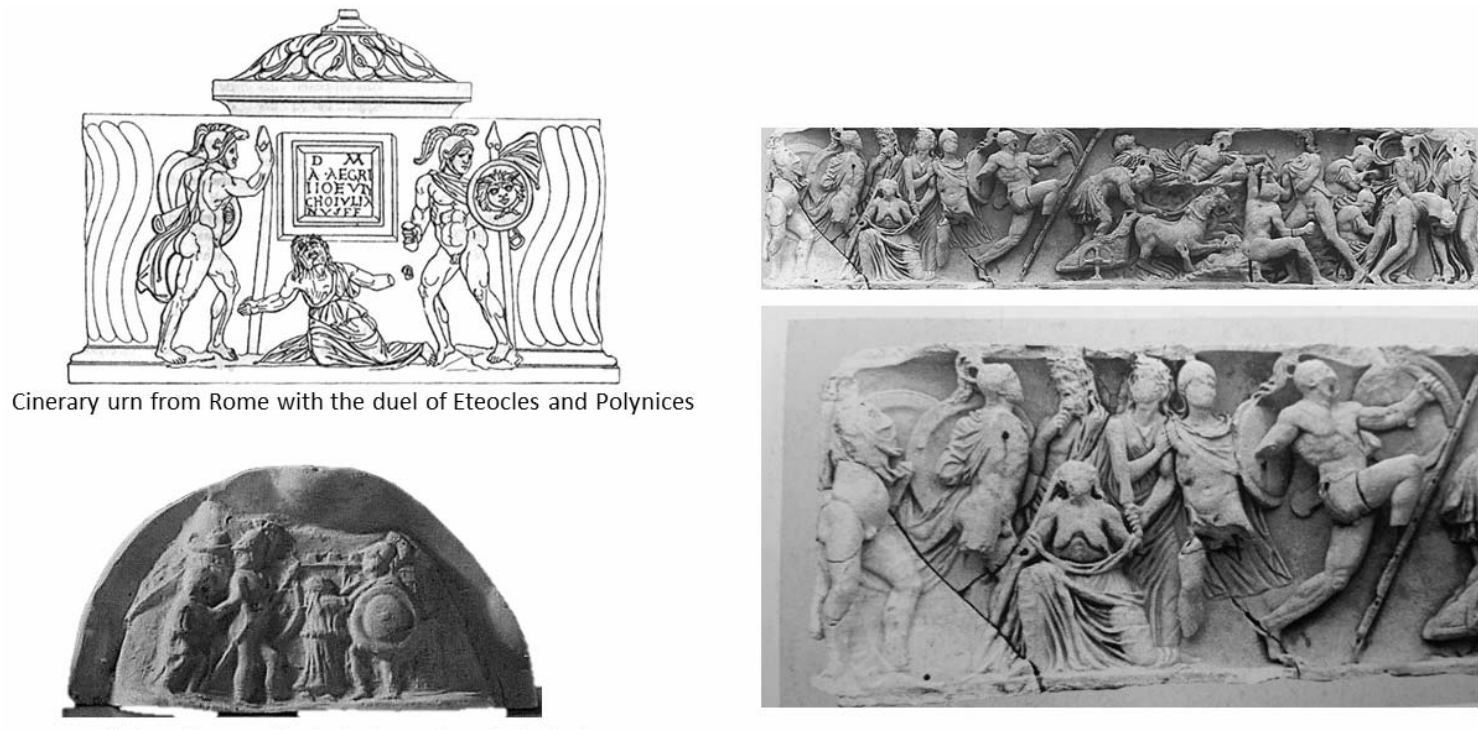

Mould for objects with depictions of mythological scenes. Found in the "Caseggiato dei Doli" $(I, I V, 5)$,

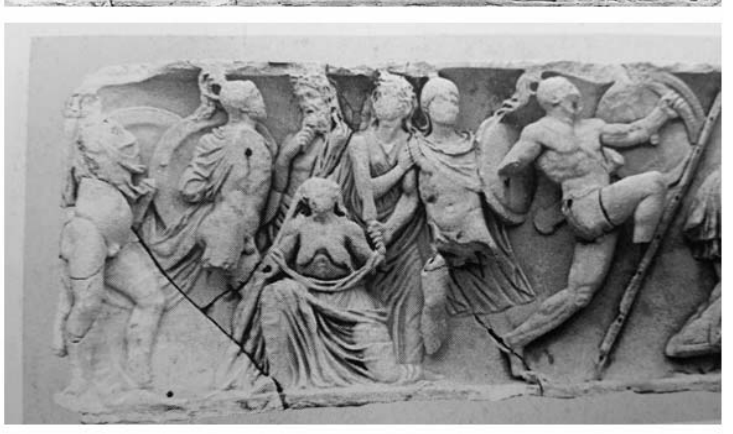

Attic sarcophagus with the myth of the «Seven against Thebes», Rome, Villa Doria Pamphilj

Fig. 2. Roman reliefs inspired by the 'Fratricides' of Pythagoras - Roma, Villa Pamphilj; Ostia, Museo Ostiense.

All the famous works of art that are inspired by the scheme of the Fratricidae of Pythagoras are characterized, as we previously said, by a warrior with a face in which it is possible to see the signs of anger, which recalls the expression on the face of Bronze A. Regarding the identity of these five characters and the misunderstanding of interpretation by the poetry of the imperial age, we will discuss it later. For now, we would like to remember how the Christian rhetorician Tatian the Syrian, in the second century, saw the Fratricidae in Rome, as evidenced by the text of his Oratio 
adversos Graecos (34.1 = Overbeck, 687), in which he states " $\pi \tilde{\omega} \varsigma$

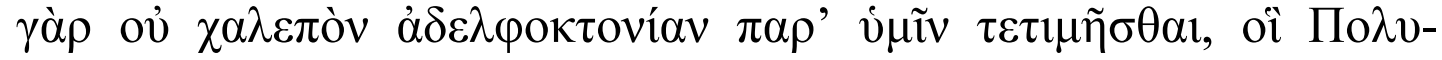

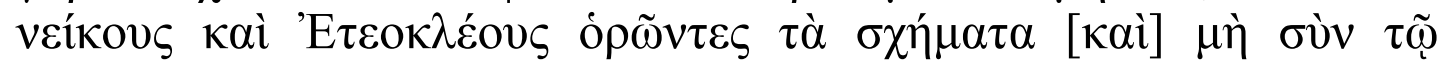

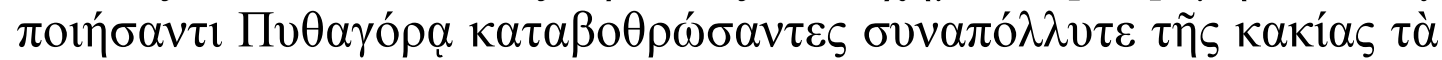

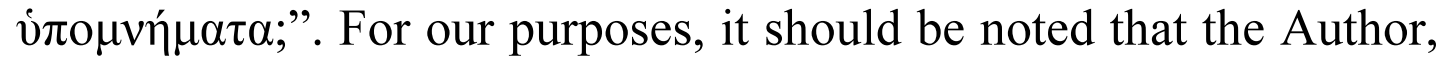
who writes in Rome just after the middle of the second century AD,

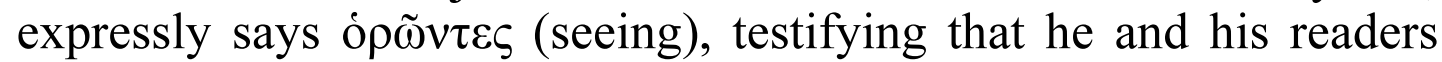
could physically observe the statuary group in the capital of the Roman Empire.

On the other hand, literary sources show that, even if it was made in Argos, there is no trace of the sculptural group in the place of origin, as shown by the text of the writer and geographer Pausanias the Periegetes who, in his Hellados Periegesis, does not mention the Fratricidae.

The lack of evidence from Argos in the second century AD, as far as we concern, could provide the proof that the statues has been raided by the Romans in previous times, an event which is probably mentioned in an epigram of Alpheus of Mytilene in the Palatine Anthology $(9,104)$ which reminds the decadence of Argos in his time, stripped of the glory of heroes.

However, the Bronzes are absent from Argos but present in Rome, as evidenced by their mention from Tatian (who saw in the City, and most likely still on the Palatine, also another illustrious work in bronze by Pythagoras, that is, Europe and the Bull). This attestation is an important piece to understand the story of the travels of the Riace Bronzes, which were made in Argos, and then stolen by the Romans. Then, after a complete restoration, they were exhibited in Rome for a few centuries. The history of the Bronzes is complete at the beginning of the fourth century, as shown by a wall of a late ancient amphora, type Agora M 273, intentionally wedged between the right wrist and the hip of Bronze A, in order to avoid a rupture of the arm during the transport operations (Fig. 3).

As evidence by the second book of The Palatine Anthology, written by Christodorus from Coptus, Constantine the Great, or his son Constantius II, ordered the transport of the statues owned by the emperor from Rome to Constantinople, at the Gymnasium of Zeuxippus.

In the framework of this operation, we believe that there are enough elements to hypothesize that the Bronzes, along with other statues, were embarked on a ship bound for Constantinople, which shipwrecked in Porto Forticchio of Riace, a port which was already known in Roman times, and which continued to be used until the Middle Ages. 

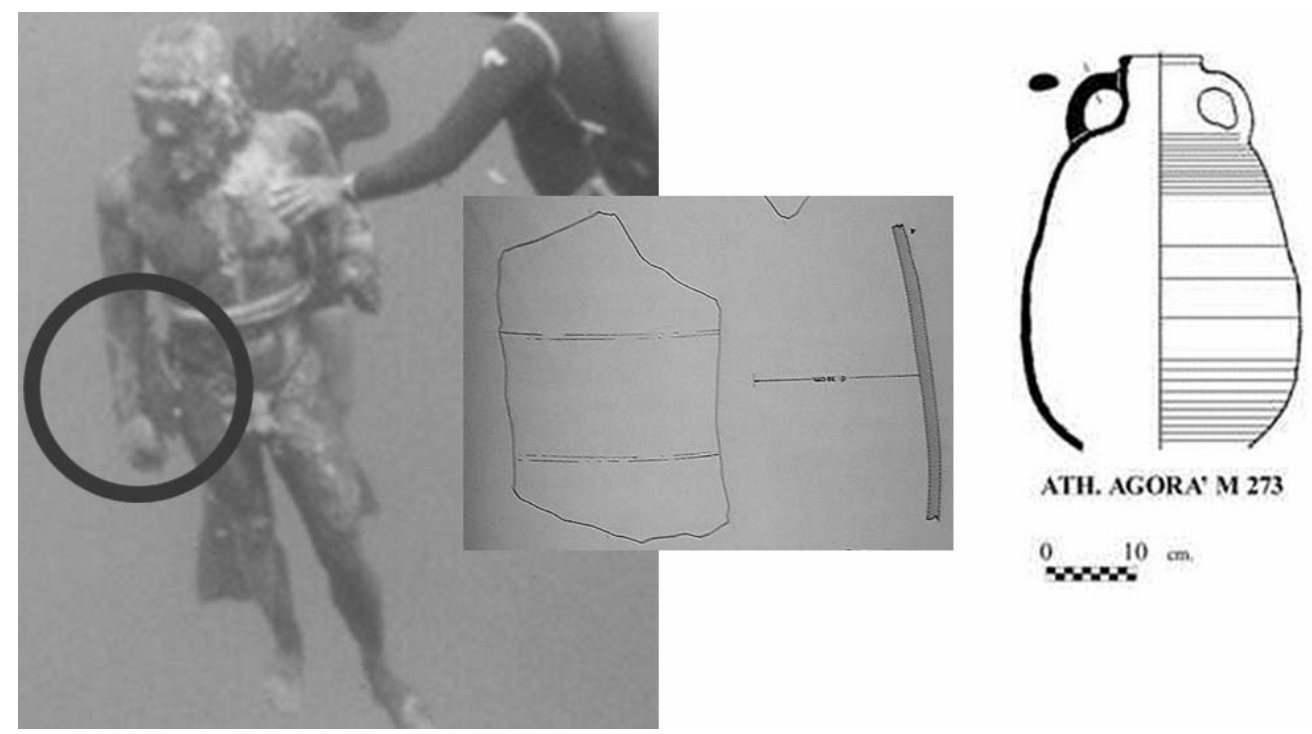

Fig. 3. Fragment of late antique amphora fixed between the wrist and the thigh of Bronze A.

\section{The duel of Eteocles and Polynices in the Thebaid of Statius}

The Christian rhetorician Tatian is not the only literary witness of the presence of the Bronzes in Rome in the Early Imperial Age. In 91 A. D. the poet Publius Papinius Statius published his Thebais, a monumental epic poem focused on the history of the Seven at Thebes: the leaders of the Argives fought to put Polynices on the throne of Thebes, against his brother Eteocles, tyrant of the city after the end of the govern of Oedipus, their father. The most terrible moment, and at the same time the most exciting, even in the midst of so many massacres, fights and blood, consists of the fratricidal duel of Eteocles and Polynices, sons of Oedipus and Jocasta, according to the version accepted by the Roman poet.

The verses 262-402 of Book XI of the Thebaid are dedicated by the poet to the phases preceding the fratricidal duel. In them, five characters take turns speaking, with often diametrically opposed opinions. The first character who appears is Creon, uncle of Eteocles and Polynices and brother of Jocasta. In his intervention, he is harsh with Eteocles, who is accused of cowardice; and he encourages his nephew to fight with Polynices for the tyranny over the city of Thebes, since all the evils were caused by his perjury with his brother. Creon persuades Eteocles, who takes up arms, but he is reached at the gate of the city by his mother Jocasta, who is upset and appears dishevelled, bare-breasted, and full of scratches.

The woman tries to convince her son not to fight, but she does not achieve the expected result. At the same time, Antigone tries to speak to his brother Polynices from the top of a tower, and she 
manages to move the hero and almost persuades him to desist from the massacre. However, when it seems that everything is about to be resolved, Eteocles goes out the door, overcoming his mother, and his arrival angers his brother, (Statius uses the expression hostile tuens, "looking at him in a hostile way") since Eteocles presents himself to his brother with all the signs of kingship: a court of friends, rich tacks for the mount and, especially the regia cassia, the helmet of the king (for us, the kynê of Bronze B - Castrizio 1988; 2007), which reminds Polynices the object of the dispute. All the previous attempts at mediation, then, are negated, and the duel becomes inevitable.

The dependence of the verses in question on the work of Pythagoras is evident if one observes, during the reading of the Latin text, an image of the Fratricidae statuary group in its most complete form, the same as the one in the left part of the front of the Attic sarcophagus which is located in Villa Doria Pamphilj in Rome, already mentioned above (Fig. 4). In the poem of Statius, as mentioned before, there are the interventions of five characters, which seem to correspond with the characters present on the sarcophagus: Eteocles, Polynices, Jocasta, Antigone and Creon. The poet expands in time the dialogues between the various characters who appear in the sculptural group. A simple reading of the verses written by Statius and dedicated to the frenetic phases that preceded the clash between Eteocles and Polynices, is enough to be certain that the poet must have been inspired by that particular bronze statuary group, as a matter of fact the poet knew he was able to admire it personally.

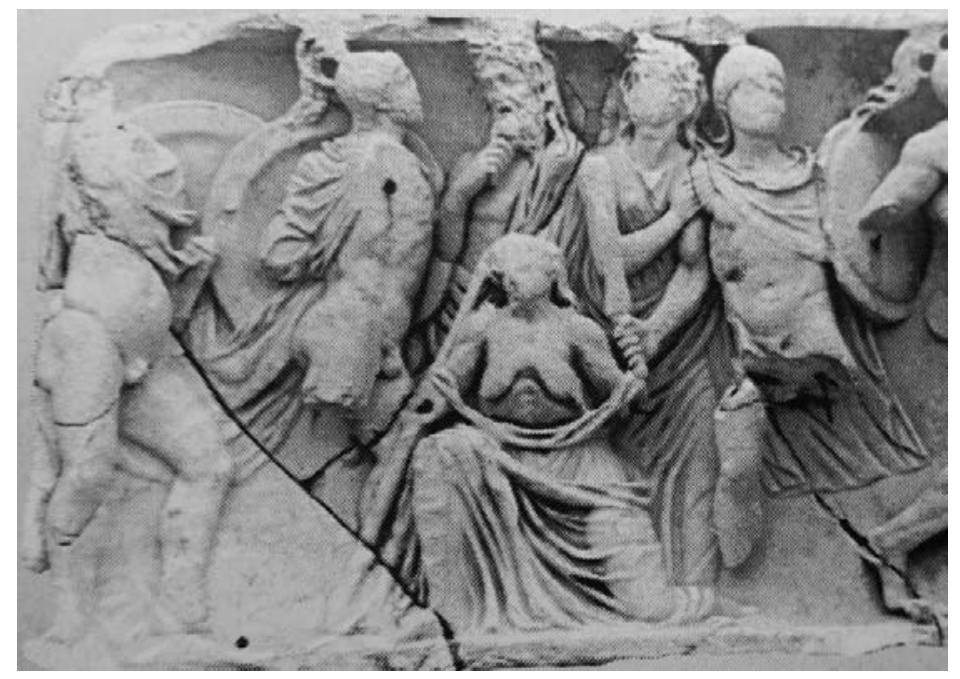

Fig. 4. Attic sarcophagus with the myth of 'Fratricides' - Roma, Villa Doria Pamphilj. 
The dependence of Statius on these works of art is, in our view, demonstrated by the fact that the poet, in addition to having used the group of Pythagoras of Rhegion in the scene of the negotiation, he showed again to be dependent to the model in which the two brothers fight in the scene of the duel of the same XI book. As a matter of fact, both brothers fight with a demon behind their backs, this scene is considered a unicum in the history of Greek art.

As it is possible to see, the statues of the Fratricidae are used by Statius as actors of a tragedy seen on scene: nothing has yet happened, and everything has already been decided. Death hovers over the two brothers, closed in their selfish point of view: it is a typical technique of representation of the Severe Period of classical art, which finds an important comparison in the two pediments of the temple of Zeus in Olympia. On the western pediment, Apollo, located at the centre of the scene, restores the order authorizing the violence against the Centaurs, guilty of having molested the women of the Lapiths at the wedding party of Pirithous and Hippodamia, at the presence of the Attic hero Theseus. On the eastern pediment, which has the same psychological tension that we find in the group of Fratricidae, Zeus ratifies the events that have not yet occurred, but that have already been decided and predestined; Pelops has already corrupted Myrtilus, charioteer of Oenomaus, king of Pisa, convincing him to sabotage the quadriga, with the consequent death of the sovereign; a soothsayer clearly foresees the betrayal and the death of the king, and, lost, touches his chin (Fig. 5), while, next to him, a slave has the index finger down, in the sign of death sentence; Pelops foretaste the marriage with Hippodamia, daughter of Oenomaus, who already appears at his side as bride.

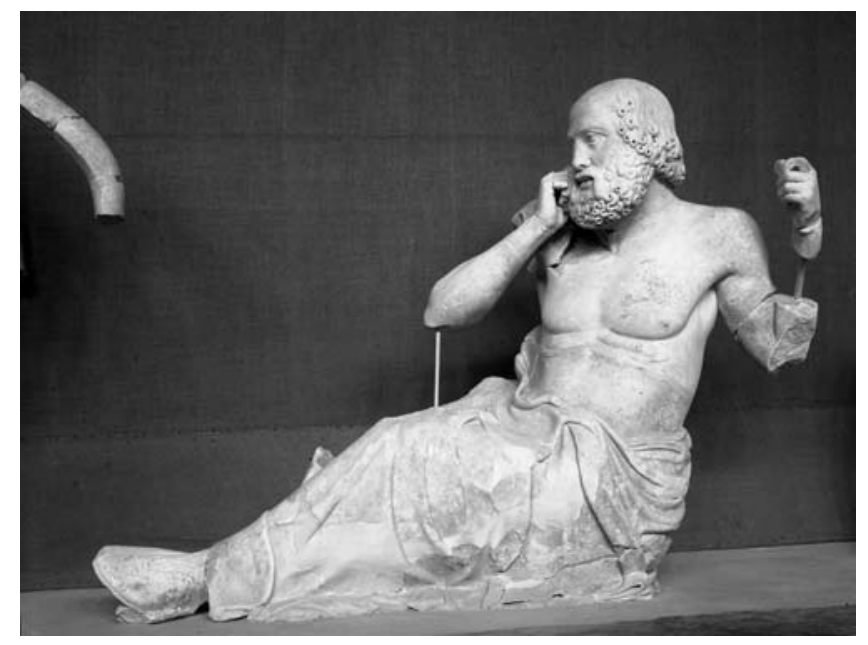

Fig. 5. Statue of a soothsayer - Olympia, Eastern pediment of the Temple of Zeus. 
As it is possible to see, every mosaic tile of the Bronzes seems to have gone in its place, but some details are not completely convincing. First of all, who is the elderly woman with uncovered breasts and tousled hair who tries to divide the two brothers in the representation of the sarcophagus? Is she Jocasta, as Statius believes? Or is she Eurigania, who in other versions of the myth is the mother of Eteocles, Polynices, Antigone and Ismene, while, in the Athenian version, Oedipus and his mother Jocasta are the parents of the four cursed sons?

Stronger perplexities concern the figure of the old man dressed in the himation that, reading the text by Statius, we have identified as Creon, who is portrayed in the same premonitory gesture of the soothsayer of the eastern pediment from Olympia. Is it really Creon, or should we see in him the soothsayer Tiresias, who plays a central role in every version of the Theban myth? According to us, to answer these questions, it is necessary to carefully read the Papyrus of Lille (Davies 1991; PMGF 222(b)), which contains an archaic version of this story, and which, almost unanimously the philologists, attribute to the great poet Stesichorus.

\section{The duel of Eteocles and Polynices in Stesichorus.}

The Papyrus of Lille handed down a fragment of a probable Thebais, in which it is possible to read a part of the speech that the mother (whose name has not been preserved: JocastalEpicasta or Eurigania?) addresses to the sons Eteocles and Polynices. In the most preserved part of the text, we read that the woman tries to convince the two brothers to accept a draw: who had won would have taken the government of the city of Thebes, while the loser, condemned to a perpetual exile, would have herds and riches.

The mother tries to use the prophecy of Tiresias to induce them to an understanding. As a matter of fact, the soothsayer Tiresias, present for the speech, foresees the death of both brothers in the event of a duel between the two. Regarding the verb epithonto in verse 234 of the Papyrus (albeit the result of a textual integration and not preserved intact), which means "they agreed", almost all philologists believed that they could temporally place the mother's speech just after the end of Oedipus' government, when the brothers agreed among themselves and Polynices headed to Argos for his voluntary exile of one year (E.g. Pepe 2007).

Honestly, this theory does not convince us for many reasons. In the first place, if Polynices had accepted a draw and having lost, 
would have left Thebes willingly, with what justification could he have returned to his homeland with weapons in hand? What would have been the fault of his brother Eteocles? In the various versions of the myth, and as Statius himself repeatedly point out with their characters, Polynices fights against his homeland because he was betrayed by the original pact, which provided that the two brothers would rule one year each, alternately. Consequently, one wonders if Adrastus, king of Argos and known for his justice, could ever have agreed to organize an expedition which was not based on a blatant injustice suffered by Polynices; on the contrary in this case, it would have been an abuse, without any legal or moral justification, in defiance of an agreement accepted by both the parties.

But there is a second argument, which is even more cogent: the Lille Stesichorus has a second part, which is very corrupted but, in broad terms, it is still understandable. Immediately after the end of the mother's speech, from the few fragments that remained readable, one can understand that Tiresias has spoken. In verse 239 there is written "taking the precious gold"; the v. 272 talks about "oxen with curved horns and horses"; in vv. 275-276 the author mentions the anax Adrastus and his beautiful daughter; in vv. 285-287 a "pain" and "the whole city" are mentioned. The impression given from these sentences is that Tiresias brutally advised Polynices to accept the gold and the herds, and to exile himself to Argos, where Adrastus had allowed him to marry his daughter. Moreover, Tiresias assumes that Polynices himself, who raised an army against his homeland, cannot remain there as the tyrant of Thebes, as if nothing had happened and forgetting the deaths caused by this war.

In our reconstruction, the intervention of Tiresias completely overturns the outcome of the negotiation, and the duel becomes inevitable. Therefore, in our view, the mother's speech takes place chronologically on the battlefield, in front of the "boundary wall" evoked in v. 295, while the two brothers are about to face each other. This is the moment when the queen tries to use all the instruments at her disposal to make her sons desist from the insane plan and she tries to scare them with the threat of the prophecy of their death and entices them with a pact. As it is possible to understand, thanks to the intervention of the soothsayer, this attempt did not have a positive outcome, and the two brothers killed each other.

In our reconstruction, the story would have been this: at the end of the government of Oedipus, the two brothers would have agreed to reign one year each; the first to rule would be Eteocles, who in this version of the myth is the elder of the two, in spite of what 
appears in the tragedies represented in Athens; after a year, Polynices would have been expelled from the government and exiled, in contrast to the insurance that he previously received. Then, the young man would have gone to Argos, where he would have married the daughter of Adrastus; after the marriage, his father-inlaw Adrastus, anax from Argos, would have organized a military expedition to give back to his son-in-law the government of Thebes. After a series of fighting, they decide to end the war under the walls of Thebes with a decisive duel between the two brothers; while they are about to face each other, the mother (Jocasta/Epicasta or Eurigania) would have intervened to stop the children, supported by his daughter Antigone and the fortune teller Tiresias. After an initial acceptance, his proposal to divide the goods between the two brothers would have been rejected and finally, in the end, as expected by the fortune teller Tiresias, the duel is fatal for both contenders.

As it can be easily observed, the scene proposed by the Papyrus of Lille is the same as the group of Fratricidae of Pythagoras of Rhegion, with the five characters interpreted as Eteocles and Polynices, the mother, the sister Antigone and the soothsayer Tiresias, not by chance this last is represented in the gesture of the one who predict the death of the protagonists.

From our reconstruction, based on the analysis and evaluation of all the data in our possession (from the reading and integration of the attributes which were originally present on the Bronzes, to the archaeometrical evaluations concerning the land of fusion; from the literary sources related to the archaeological comparisons that we know; from the iconography to the history) it can be concluded that we are faced with a real unicum in the history of Greek art. Apart from the extraordinary technical and artistic quality of the two statues from Riace, we are able to read the source of inspiration of the bronze maker, that for us is Pythagoras from Reggio: it is the Thebais of Stesichorus and in particular the verses testified by the Lille Stesichorus, in which a desperate mother tries the last attempt to prevent the death of her sons. All the characters of the Papyrus of Lille are staged, and thanks to that, it is possible to understand the words of the woman placed at the centre of the scene, while the two sons, as actors in the theatre, are represented with a diametrically opposite attitude: one is closed in his own hostility (Bronze A), while the other appears perfectly aware of his own destiny of death, incapable to look his brother in the eyes (Bronze B). 
By chance, it is also possible to read the interpretation that Papinius Statius gives of the statuary group of the Fratricidae of Pythagoras from Rhegion, with Creon in the place of Tiresias, which, it should be highlighted, shows the limits of the Roman antiques culture of the first century $\mathrm{AD}$, which had begun to lose the contribution of the great literary schools of Magna Graecia and Sicily, and that close in the Atticism of historians and tragedians, which still today permeates the majority the studies on ancient Greece.

\section{The original color of the Bronzes}

Literary sources can offer a decisive contribution to the original colour of the Bronzes. Even knowing Mr Brinkmann's proposal, which has no justification or supporting evidence, we will try, in opposition, to follow a scientific path based on the crossing of literary sources and archaeometric data (Brinkmann 2015). In this work we were facilitated by the progress of research and new data from the Japanese team, led by Prof. Koichi Hada, who imposed a further examination on the original colour of the Bronzes, that followed the in-depth analysis of ancient sources regarding the way to protect and colour bronze statues. The safest method to manage skin coloration consisted of create the coating using sulphur, on which it is possible to apply bitumen, known by Pliny as asphaltos (Naturalis Historia, 34.15).

Studies on colouring of ancient statues are still at the beginning, but regarding the Riace Bronzes, we have been able to make use of the experimentation on bronze samples that have the same percentage of copper and tin of the two statues (Formigli 1984). The percentages were obtained from the studies of Formigli, resumed experimentally by Koichi Hada and the Japanese artist Takashi Matsumoto ${ }^{10}$, the two researcher who allowed to the creation of models by means of ancient construction techniques, similar to those of the Greek world. The result of these tests shows a golden colour of bronze (Fig. 6), thanks to a much higher percentage of tin than the percentage that is normally used. This unusual alloy has a negative aspect, which is the greater weakness of the bronze statue, however, it is counterbalanced by a greater fluidity of the metal, useful to make the details, and, above all, the splendid golden coloration. It is the colour that the Romans, in the imperial era, obtained using the

${ }^{10}$ Matsumoto, Hada 2020a; 2020b; 2020c; 2020d; 2020e. 
gilding of bronze, and the colour that the Bronzes have since their origin.

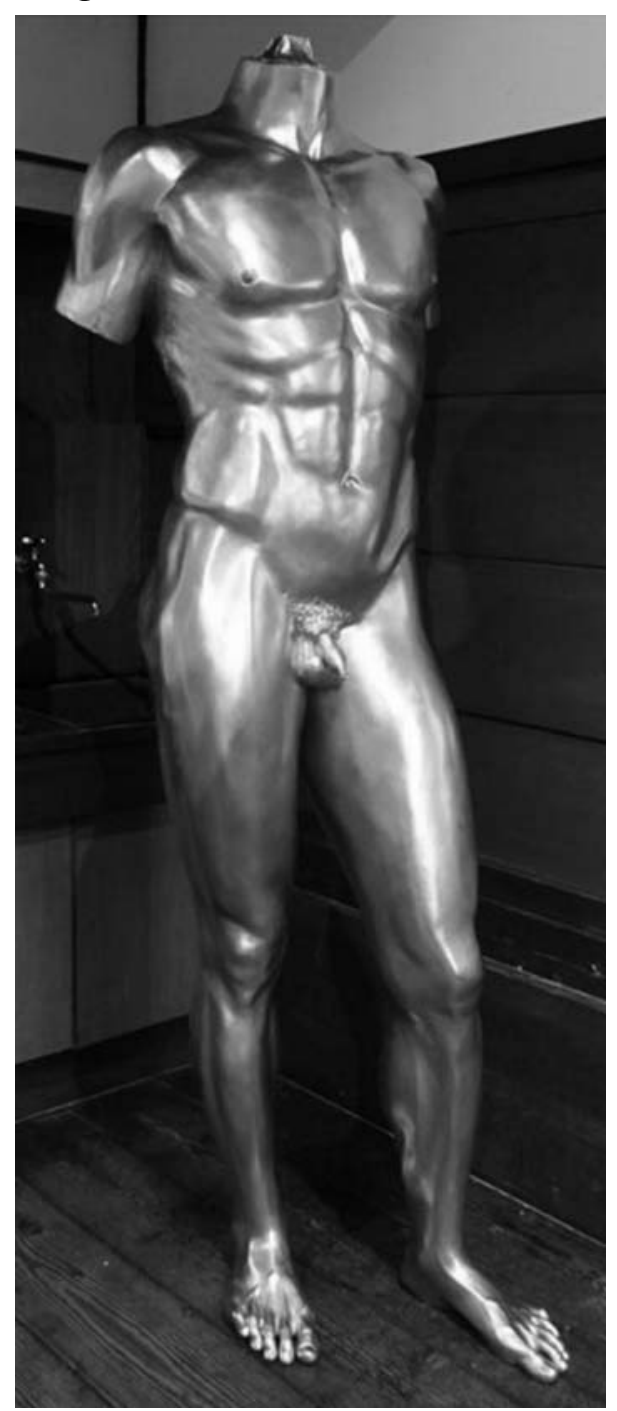

Being in possession of these data, our team of researchers examined the original colour of the finished work, starting from some general considerations. First, it has to be remarked that the polychrome of the Bronzes is absolutely certain, as evidenced by the lips and nipples, made red by the use of copper, as well as by the eyes in calcite and glass paste, and by the small pink stone used to reproduce the caruncola lacrimalis and, in the case of Bronze A, by the white teeth in silver. With these premises, we analysed the reason for the decision to create an alloy that makes bronze golden. Observing many marks still present on the beard and hair of the two statues from Riace, we came to the conclusion that this colour was chosen because the two heroes was imagined with blond hair and beards, as in almost every exhibit which have preserved traces of the original colour.

Fig. 6. Modern reproduction of Bronze A, with the original colour after the fusion - Work of the artist Takashi Matsumoto, on indications of Prof. Koichi Hada.

Regarding the skin colour, thanks to empirical experimental evidences, realised using the "liver of sulphur" (a mixture of potassium sulphide, potassium polysulfide, potassium thiosulfate, and likely potassium bisulfide, which is still used to burnish the bronze) (Fig. 7), we chose to present the Bronzes with a tanned skin colour not very dark, being aware of the arbitrariness of our choice for the possible shades of colour, but also aware of being in line with the chromatism that can be recognized in the surviving works. The result of the research is summarized in the images made by the graphic designer Saverio Autellitano (Figg. 8, 9, 10), which show our attempt to read two ancient works using ancient sources, 
archaeometric data and the contribution of iconographic research in the field of Greek art history.

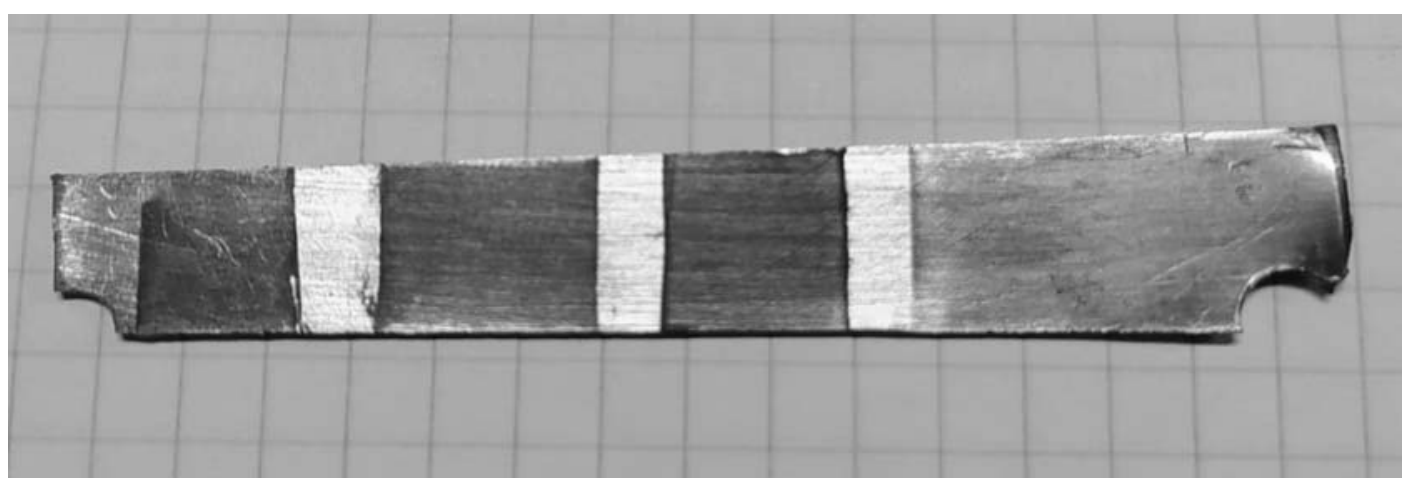

Fig. 7. Experimental fusion with the exact percentages of Copper and Tin, with skin color tests, by sulfur liver - Laboratory of Domenico Colella, Reggio Calabria.

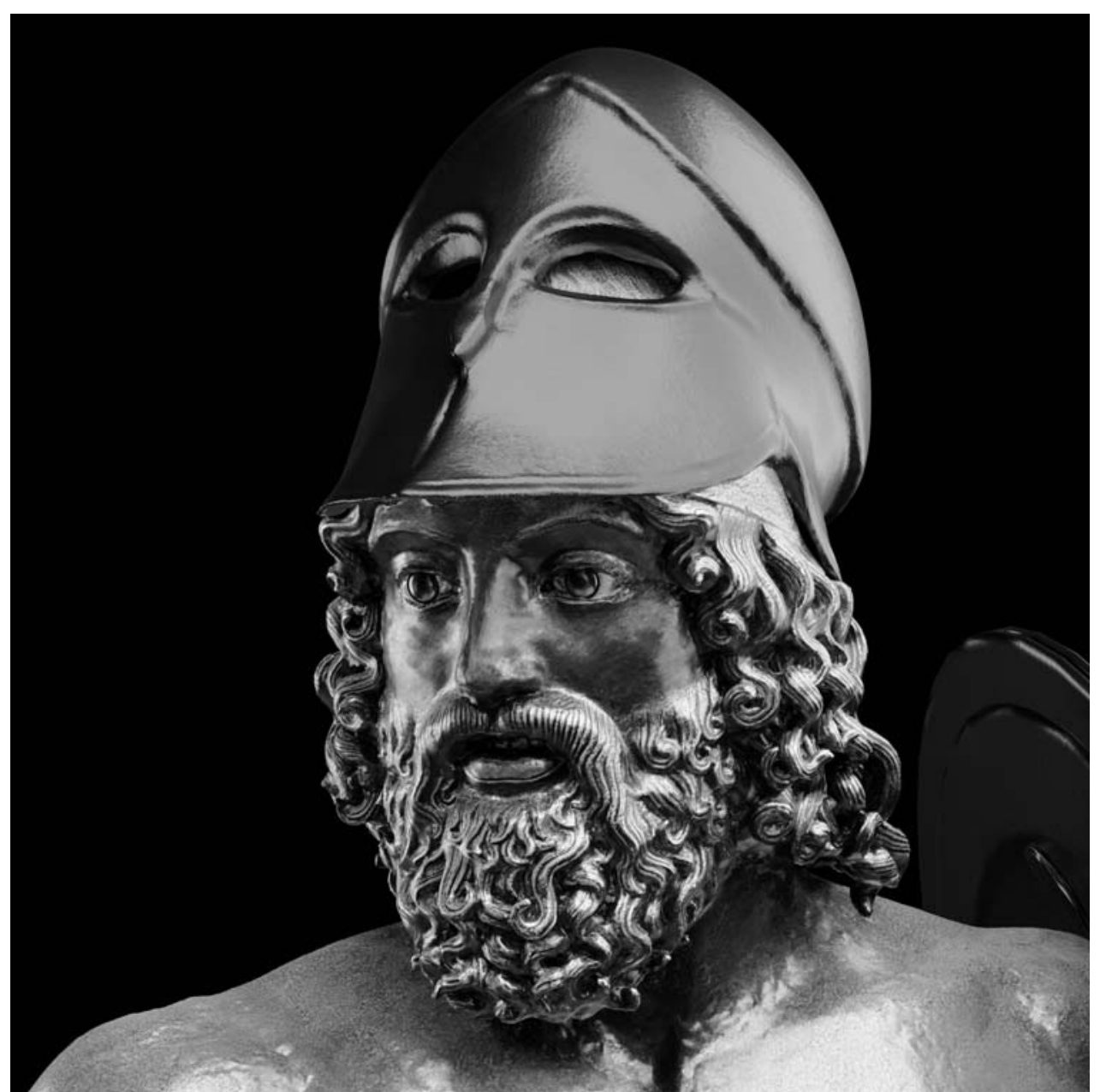

Figg. 8-9-10. Proposal of the original coloring of the Riace Bronzes Graphic design by Saverio Autellitano. 


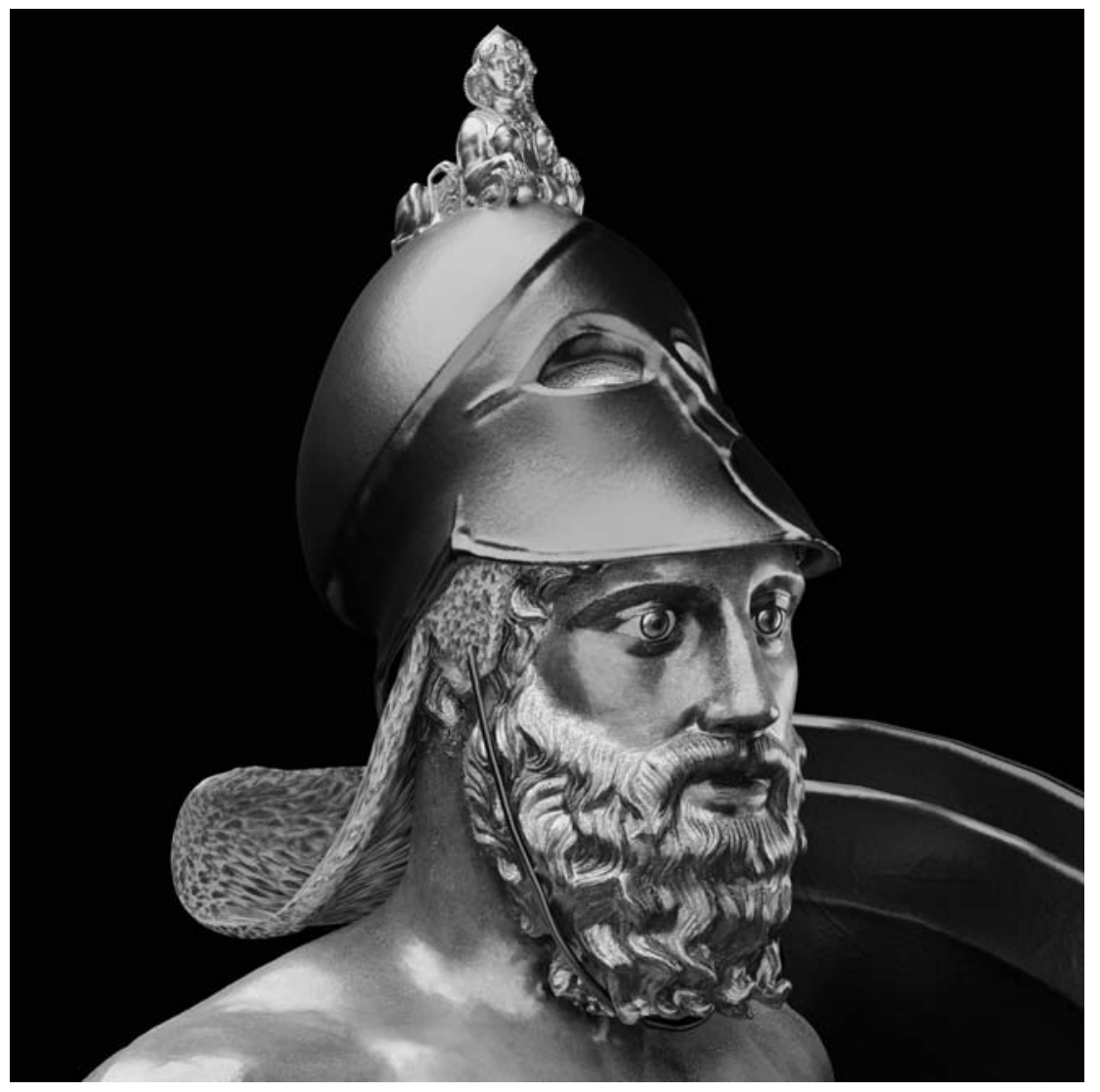

Fig. 9.

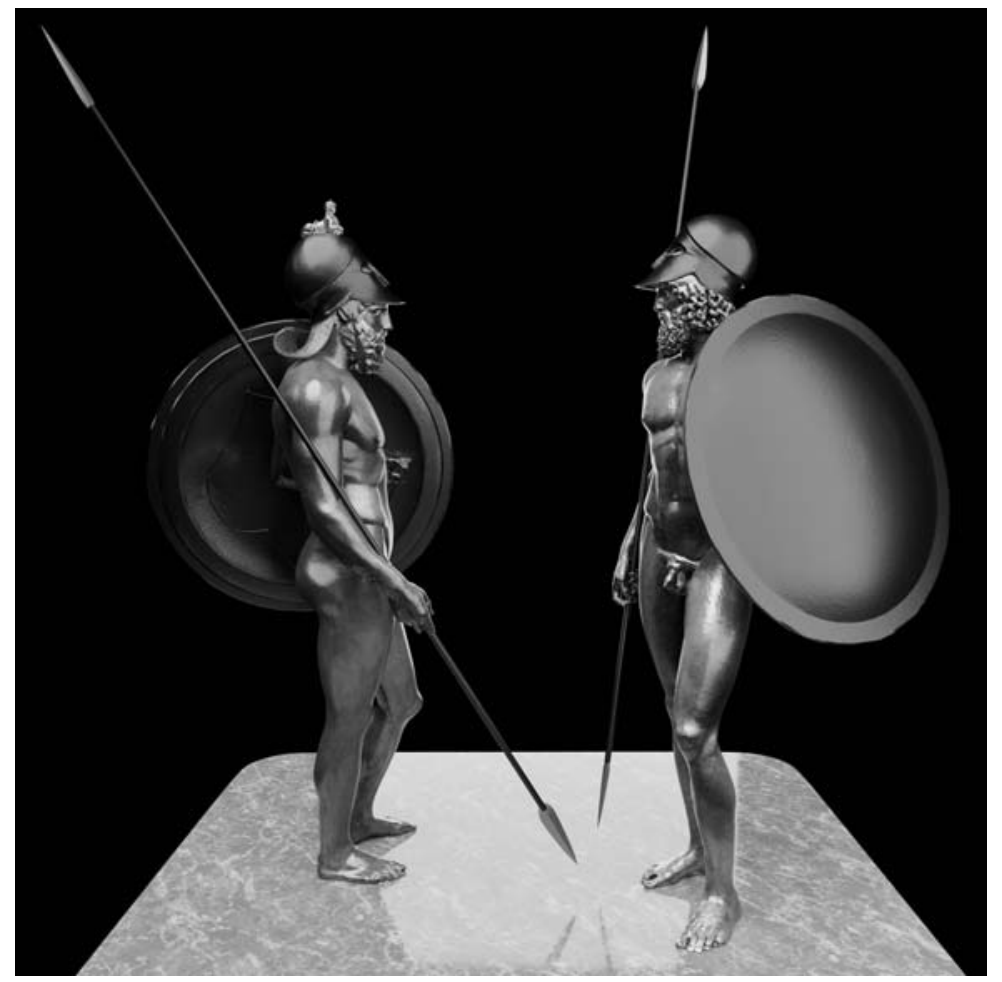

Fig. 10. 


\section{References}

Arias, P. E. 1984: Lettura delle statue bronzee di Riace. In: $A A . V V$., Due Bronzi da Riace, Rinvenimento, restauro, analisi e ipotesi di interpretazione, a cura di L. Vlad Borrelli e P. Pelagatti, II, Roma (Bollettino d'Arte, Serie speciale, III), 243-250.

Arias, P. E. 1986: Analisi critica delle statue. In: AA.VV., Gli Eroi venuti dal mare, a cura di L. M. Lombardi Satriani e M. Paoletti, Roma, $39-64$.

Brinkmann, V. 2015: Art of Many Colours. Classical Statues in Their Original Appearance. In: AA.VV., Serial/Portable Classic: The Greek Canon And Its Mutation, (a cura di Salvatore Settis, Anna Anguissola, Davide Gasparotto). Milano, 95-100

Buccolieri, G., Buccolieri, A., Donati, P., Marabelli, M., Castellano, A. 2015: Portable EDXRF investigation of the patinas on the Riace Bronzes. In: Nuclear Instruments and Methods in Physics Research Section B: Beam Interactions with Materials and Atoms 343, 101109.

Castrizio, D. 1988: La KOPINOIH KYNH nelle emissioni monetali e nella statuaria di età classica. In: Quaderni Ticinesi di Numismatica e antichità classiche XXVII, 83-104.

Castrizio, D. 2000: I Bronzi di Riace. Ipotesi ricostruttiva. Reggio Calabria.

Castrizio, D. 2004: Segni di comando militare sugli elmi nelle monete greche di epoca classica ed ellenistica. In: L'immaginario e il potere nell'iconografia monetale. Dossier di lavoro del seminario di studi, Milano 11 marzo 2004 (a cura di L. Travaini e A. Bolis), Milano, 41-54.

Castrizio, D. 2007: L'elmo quale insegna del potere. LIN 3, Reggio Calabria.

Castrizio, D. 2011: Guida alla statuaria reggina. Nuove ipotesi e interpretazioni. Reggio Calabria.

Castrizio, D., Iaria C. 2016: Bronzi di Riace. Riace Bronzes. Reggio Calabria.

Castrizio, D. 2018: L'Europa su toro di Pythagóras di Rhegion: un capolavoro ritrovato? AMSMG. Pisa; Roma, 27-36.

Castrizio, D. 2019: The Riace Bronzes. Recent research and new scientific knowledge. In: VIII Международная научная конференция «Актуальные проблемы теории и истории искусства» / 8th International Conference Actual Problems Of Theory And History Of Art. Moscow 2-6 ottobre 2018, St. Petersburg, 62-69.

Castrizio, D. 2020: I Bronzi di Riace. Ricerche recenti e nuove conoscenze scientifiche. In: I Bronzi di Riace. Studi e ricerche, a cura di Malacrino C.G. e Castrizio D., Atti del Convegno, Reggio Calabria - Messina, 25-26 ottobre 2018, Reggio Calabria, 43-56. 
Davies, M. 1991: Poetarum Melicorum Graecorum Fragmenta, I, Clarendon Press, Oxford.

Di Vita, A. 1984: Due capolavori attici: gli oplitodromi - eroi di Riace. In: AA.VV., Due Bronzi da Riace, Rinvenimento, restauro, analisi e ipotesi di interpretazione, a cura di L. Vlad Borrelli e P. Pelagatti, II, Roma (Bollettino d'Arte, Serie speciale, III), 251-276.

Dontàs, G. 1984: Considerazioni sui due bronzi di Riace: proposte sui maestri e sulla provenienza delle statue. In: $A A . V V$., Due Bronzi da Riace, Rinvenimento, restauro, analisi e ipotesi di interpretazione, a cura di L. Vlad Borrelli e P. Pelagatti, II, Roma (Bollettino d'Arte, Serie speciale, III), II, 277-298.

Dontàs, G. 1985-1988: Some remarks on the bronze statues of Riace Marina. In: AA.VV., Actes du XII Congrès International d'Archéologie Classique. Athènes 1983, I, Athina; II, 89-96.

Formigli, F. 1984: La tecnica di costruzione. In: AA.VV., Due Bronzi da Riace, Rinvenimento, restauro, analisi e ipotesi di interpretazione, a cura di L. Vlad Borrelli e P. Pelagatti, II, Roma 1984 (Bollettino d'Arte, Serie speciale, III), 107-142.

Giuliano, A. 1981: I grandi Bronzi di Riace. Xenia 2, 55-60.

Giuliano, A. 1982: I grandi Bronzi di Riace. Xenia 3,41-46.

Giuliano, A. 1983: I grandi Bronzi di Riace. Xenia 5, 5-6.

Giuliano, A. 1984: I grandi Bronzi di Riace, Fidia e la sua officina. In: AA.VV., Due Bronzi da Riace, Rinvenimento, restauro, analisi e ipotesi di interpretazione, a cura di L. Vlad Borrelli e P. Pelagatti, II, Roma (Bollettino d'Arte, Serie speciale, III), 297-306.

Jones, R., Brunelli, D., Cannavò, V., Levi, S. T., Vidale, M. 2016: The Riace bronzes: recent work on the clay cores. In: BAR S2780, Proceedings of the 6th Symposium of the Hellenic Society for Archaeometry (Edited by E. Photos-Jones in collaboration with Y. Bassiakos, E. Filippaki, A. Hein, I. Karatasios, V. Kilikoglou and E. Kouloumpi), London, 221-27.

Mannoni T. 1984: Le terre di riempimento delle statue e i frammenti ceramici: analisi mineralogico-petrografiche in relazione alla provenienza dei bronzi. In: AA.VV., Due Bronzi da Riace, Rinvenimento, restauro, analisi e ipotesi di interpretazione, a cura di L. Vlad Borrelli e P. Pelagatti, II, Roma (Bollettino d'Arte, Serie speciale, III), 29-30.

Matsumoto, T., Hada, K. 2020a: Ricostruzione sperimentale della forma dei Bronzi di Riace. In: I Bronzi di Riace. Studi e ricerche, a cura di Malacrino C. G. e Castrizio D., Atti del Convegno, Reggio Calabria - Messina, 25-26 ottobre 2018, Reggio Calabria, 57-70.

Matsumoto, T., Hada, K. 2020b: Saldatura per colata a ovali continui applicata ai Bronzi di Riace. Osservazioni. In: I Bronzi di Riace. Studi e ricerche, a cura di Malacrino C. G. e Castrizio D., Atti del Convegno, Reggio Calabria - Messina, 25-26 ottobre 2018, Reggio Calabria, 71-82. 
Matsumoto, T., Hada, K. 2020c: Saldatura per colata a ovali continui applicata ai Bronzi di Riace. Fusione sperimentale. In: I Bronzi di Riace. Studi e ricerche, Atti del Convegno, a cura di C.G. Malacrino e D. Castrizio, Reggio Calabria - Messina, 25-26 ottobre 2018, Reggio Calabria,83-94.

Matsumoto T., Hada K. 2020d: L'eventuale "fusione a parte" della gamba sinistra del Bronzo A di Riace. In: I Bronzi di Riace. Studi e ricerche, a cura di Malacrino C. G. e Castrizio D., Atti del Convegno, Reggio Calabria - Messina, 25-26 ottobre 2018, Reggio Calabria, 95-100.

Matsumoto, T., Hada, K. 2020e: Presunte procedure di costruzione dei Bronzi di Riace. In: I Bronzi di Riace. Studi e ricerche, a cura di Malacrino C. G. e Castrizio D., Atti del Convegno, Reggio Calabria - Messina, 25-26 ottobre 2018, Reggio Calabria, 101-116.

Micheli, M., Vidale, M. 1996: Bronzi di Riace, Restauro, in Enciclopedia dell'arte antica classica e orientale. Secondo Supplemento, IV. Roma, 734.

Micheli, M., Vidale, M. 2003: I Bronzi di Riace, Restauro come conoscenza, vol. 2 Scavo dell'interno delle due statue. Roma.

Moreno, P. 1998: I Bronzi di Riace. Il Maestro di Olimpia e i Sette a Tebe. Milano.

Paribeni, E. 1984: I Bronzi di Riace. In AA.VV., Due Bronzi da Riace, Rinvenimento, restauro, analisi e ipotesi di interpretazione, a cura di L. Vlad Borrelli e P. Pelagatti, II, Roma (Bollettino d'Arte, Serie speciale, III), 307-312.

Paribeni, E. 1986: Lo stile e la datazione. In: AA.VV., Gli Eroi venuti dal mare, a cura di L.M. Lombardi Satriani e M. Paoletti, Roma, 65-76.

Parisi Presicce, C., Touchette, L.-A. 2002: A "rediscovered" colossal bronze bull in the Conservatori Museum. In: From the parts to the whole. Acta of the $13^{\text {th }}$ International Bronze Congress, Cambridge, Massachusetts, may 28-june 1, 1996 (JRA. Supplementary series, 39), II, a cura di C. C. Mattusch, A. Brauer e S. E. Knudsen, Portsmouth, 73-82.

Pepe, L. 2007: I «Sette contro Tebe» e la spartizione dell'eredità di Edipo. In: Diritto e Teatro in Grecia e a Roma, a cura di E. Cantarella e L. Gagliardi, Milano, 31-67.

Rebaudo, L. 2020: I Bronzi di Riace: archeologia e archeometria. In: I Bronzi di Riace. Studi e ricerche, a cura di Malacrino C. G. e Castrizio D., Atti del Convegno, Reggio Calabria - Messina, 2526 ottobre 2018, Reggio Calabria, 23-42.

Rolley, C. 1983: Les Bronzes grecs. Paris.

Rolley, C. 1984: Delphes? Non! In: AA.VV., Due Bronzi da Riace, Rinvenimento, restauro, analisi e ipotesi di interpretazione, a cura di L. Vlad Borrelli e P. Pelagatti, II, Roma (Bollettino d'Arte, Serie speciale, III), 327-332. 
Roma, G. 2007: I Bronzi di Riace: brevi considerazioni. Ostraka - Rivista di Antichità XVI 2, Luglio-Dicembre, 391-400.

Ross Holloway, R. 1975: Influences and Styles in the Late Archaic and Early Classical Greek Sculpture of Sicily and Magna Graecia, Louvain.

Ross Holloway, R. 1978: Gli Eroi di Riace sono siciliani? Sicilia Archeologica 66-68, 23-29.

Sismondo Ridgway, B. 1984: The Riace Bronzes: a minority viewpoint. In: AA.VV., Due Bronzi da Riace, Rinvenimento, restauro, analisi e ipotesi di interpretazione, a cura di L. Vlad Borrelli e P. Pelagatti, II, Roma (Bollettino d'Arte, Serie speciale, III), 313-326.

Stucchi, S. 1986: Le due statue di bronzo dal mare di Riace, Una revisione. Atti dell'Accademia Nazionale dei Lincei, Rendiconti XLI, 111-135.

Stucchi, S. 1988: Nuove osservazioni sulle statue bronzee di Riace. Atti dell'Accademia Nazionale dei Lincei, Rendiconti XLIII, 99-102. 